\title{
Human papillomavirus DNA in squamous cell carcinoma of the lung
}

\author{
T Hirayasu, T Iwamasa, Y Kamada, Y Koyanagi, H Usuda, K Genka
}

\section{Department of Pathology, \\ Ryukyu University \\ School of Medicine, \\ 207 Uehara Nishihara \\ Okinawa 903-01, Japan \\ T Hirayasu \\ T Iwamasa}

\section{Department of}

Surgery

Y Kamada

\section{Department of Microbiology, Tokyo Medical and Dental University School of Medicine, Yushima, Bunkyoku, Tokyo 113, Japan \\ Y Koyanagi}

Department of Pathology, Niigata University School of Medicine, Asahimachi dori, Niigata 757, Japan H Usuda

\section{Department of}

Surgery,

National Okinawa

Hospital,

Ginowan, Okinawa

901-22, Japan

K Genka

Correspondence to:

Dr T Hirayasu.

Accepted for publication 20 February 1996

\begin{abstract}
Aim-To compare the incidence of squamous cell carcinoma (SCC) of the lung in Okinawa with that in Niigata on the mainland.

Methods-All patients presenting with SCC of the lung in Okinawa and Niigata in 1993 were included in the study. Diagnoses were confirmed by conventional histological examination of paraffin wax sections. Human papillomavirus (HPV) was detected by non-isotopic in situ hybridisation (NISH) and polymerase chain reaction (PCR) amplification with primers specific for the E6 and E7 regions of the HPV genome. PCR products were analysed by Southern and dot blotting. Results-The incidence of well differentiated SCC of the lung was high in patients from Okinawa compared with moderately and poorly differentiated types, and compared with the incidence of SCC in patients from Niigata. This is despite similar patterns of age, sex (predominatly male), and smoking habit. More patients from Okinawa, however, were positive for HPV DNA by PCR (79\%) and NISH (53\%). Many patients haboured HPV types 6,16 , and 18 . Only $30 \%$ of patients from Niigata were positive for HPV DNA by PCR and $20 \%$ by NISH. These patients all harboured one HPV type only.

Conclusion-Surprisingly large numbers of patients from Okinawa were positive for HPV DNA. The detection of HPV DNA was strongly associated with well differentiated SCC. This was particularly true for HPV types 6 and 16. There was no correlation between either smoking and detection of HPV DNA, or smoking and histological differentiation.

(f Clin Pathol 1996;49:810-817)
\end{abstract}

Keywords: human papillomavirus, in situ hybridisation, PCR, squamous cell carcinoma of the lung.

Lung cancer is the most common cause of death from cancer worldwide. In Okinawa prefecture, a subtropical island in southern Japan, the incidence of lung cancer is the highest of all of the malignant neoplasms ${ }^{1}$ and is also higher than that in other areas of Japan. ${ }^{2}$ Well differentiated squamous cell carcinoma (SCC) of the lung is prevalent in Okinawa, ${ }^{3}$ but is relatively rare on the mainland. Saldana ${ }^{4}$ reported that well differentiated squamous cell carcinoma (SCC) of the lung was relatively rare in the USA. But in the 1950s well differentiated cases were frequently observed in mainland Japan. Miyaji ${ }^{5}$ examined 1152 cases of lung carcinoma throughout the mainland, and reported that in the period 1958-9 there were 72,20 , and 24 cases, respectively, of well, moderately, and poorly differentiated SCC of the lung.

It has been reported that the incidence of carcinoma of the lung closely correlates with a heavy smoking habit, with a lag of between 30 and 40 years. ${ }^{6}$ Epidemiologists have provided overwhelming evidence that cigarette smoking is the major cause of lung carcinoma. ${ }^{78}$ Other environmental agents have also been reported, and many act in concert with cigarette smoking. ${ }^{6}$ But the prevalence of smoking in Okinawa, in general, is not particularly high. ${ }^{9}$ There is virtually no heavy industry or mining in Okinawa. Investigations into the aetiological factors and the pattern of histological differentiation of lung carcinoma in Okinawa are therefore of vital importance.

Bejui-Thivolet et al ${ }^{10}$ reported that human papillomavirus (HPV) was present in $16 \%$ of cases of SCC and squamous metaplasia of the lung by in situ hybridiation. Yousen $e t a l^{11}$ also studied HPV DNA in 16 cases of SSC of the lung, one of which was positive for HPV 6 and/or $11 \mathrm{DNA}$, two for 16 and/or $18 \mathrm{DNA}$, and two for 31 and/or 33 DNA, using commercially available DNA probes for in situ hybridisation. About $60 \%$ (by Southern blotting) and $90 \%$ (by PCR) of well and moderately differentiated cases of SCC of the head and neck, from North Carolina in the USA, were positive for HPV DNA. ${ }^{12}$ A high prevalence $(76 \%)$ of HPV infection in oral epidermoid carcinomas has also been reported from Taiwan, ${ }^{13}$ the nearest neighbour to Okinawa.

To our knowledge there has been no report on the relation between histological differentia- $\mathcal{C}^{2}$ tion of squamous cell carcinoma of the lung, and on the detection of HPV DNA, especially in subtropical and tropical regions.

\section{Methods}

Samples of SCC of the lung $(n=43)$ were obtained from the National Okinawa Hospital and Ryukyu University Hospital $(\mathrm{n}=51)$. These were all cases of SCC coming to surgery in 1993. Lung carcinoma was classified as follows: adenocarcinoma $\mathrm{n}=39$; squamous cell carcinoma $n=43$; large cell carcinoma $n=3$; small cell carcinoma $\mathrm{n}=3$; adenosquamous carcinoma $\mathrm{n}=5$; and mucoepidermoid carcinoma $\mathrm{n}=1$.

We compared these cases with those of mainland Japan (Niigata Prefecture). Okinawa 
Table 1 Demographic details of patients with squamous cell carcinoma of the lung from Okinawa

\begin{tabular}{|c|c|c|c|c|c|c|}
\hline Case & Sex & Age & Location & Stage & $\begin{array}{l}\text { Tobacco } \\
\text { smoking } \\
\text { (numbers/ } \\
\text { days } \times \text { years) }\end{array}$ & Occupation \\
\hline 1 & Male & 63 & Central & I & $30 \times 44$ & Farmer \\
\hline 2 & Male & 82 & Central & I & $20 \times 60$ & Farmer \\
\hline 3 & Male & 67 & Central & 0 & $20 \times 43$ & Carpenter \\
\hline 4 & Male & 77 & Central & I & $20 \times 62$ & Farmer \\
\hline 5 & Male & 82 & Central & I & $20 \times 60$ & Farmer \\
\hline 6 & Male & 69 & Central & 0 & $5 \times 50$ & Farmer \\
\hline 7 & Male & 66 & Central & I & ? & Fisherman \\
\hline 8 & Female & 78 & Central & I & ? & ? \\
\hline 9 & Male & 66 & Central & IIIa & $20 \times 51$ & ? \\
\hline 10 & Male & 75 & Central & II & $30 \times 37$ & Fisherman \\
\hline 11 & Male & 64 & Central & I & $10 \times 43$ & Farmer \\
\hline 12 & Male & 71 & Central & I & $40 \times 55$ & Farmer \\
\hline 13 & Male & 76 & Central & I & $40 \times 57$ & $?$ \\
\hline 14 & Male & 67 & Central & I & $25 \times 43$ & Fisherman \\
\hline 15 & Male & 67 & Central & I & $50 \times 41$ & Petrol station attendant \\
\hline 16 & Male & 69 & Central & I & $20 \times 50$ & Farmer \\
\hline 17 & Female & 68 & Central & I & $30 \times 11$ & Flower shop sales assistant \\
\hline 18 & Male & 66 & Central & I & ? & ? \\
\hline 19 & Male & 72 & Peripheral & I & $20 \times 53$ & Fisherman \\
\hline 20 & Male & 82 & Peripheral & I & $40 \times 51$ & $?$ \\
\hline 21 & Male & 70 & Peripheral & IIIa & $30 \times 47$ & Fisherman \\
\hline 22 & Male & 63 & Peripheral & I & $40 \times 29$ & Fisherman \\
\hline 23 & Male & 78 & Peripheral & I & $10 \times 55$ & ? \\
\hline 24 & Male & 70 & Peripheral & I & $?$ & Farmer \\
\hline 25 & Male & 63 & Peripheral & I & $20 \times 44$ & Carpenter \\
\hline 26 & Male & 70 & Peripheral & I & $20 \times 51$ & Farmer \\
\hline 27 & Male & 61 & Peripheral & I & $20 \times 40$ & ? \\
\hline 28 & Male & 63 & Peripheral & I & $30 \times 47$ & Postmaster \\
\hline 29 & Male & 57 & Peripheral & I & $20 \times 40$ & Newspaper reporter \\
\hline 30 & Male & 66 & Peripheral & I & $24 \times 47$ & ? \\
\hline 31 & Male & 77 & Peripheral & IV & $7 \times 62$ & Fisherman \\
\hline 32 & Male & 63 & Peripheral & I & $25 \times 43$ & Fisherman \\
\hline 33 & Male & 64 & Peripheral & II & $20 \times 44$ & Fisherman \\
\hline 34 & Male & 71 & Peripheral & I & $30 \times 55$ & Fisherman \\
\hline 35 & Female & 32 & Peripheral & I & $15 \times 6$ & Housewife \\
\hline 36 & Female & 79 & Peripheral & I & $10 \times 46$ & Housewife \\
\hline 37 & Male & 70 & Peripheral & IIIa & $40 \times 50$ & Farmer \\
\hline 38 & Male & 61 & Peripheral & I & $20 \times 36$ & $?$ \\
\hline 39 & Male & 66 & Peripheral & I & $20 \times 47$ & Fisherman \\
\hline 40 & Male & 68 & Peripheral & I & $100 \times 41$ & High school teacher \\
\hline 41 & Male & 75 & Peripheral & IIIa & $25 \times 50$ & Fisherman \\
\hline 42 & Male & 59 & Peripheral & I & ? & $?$ \\
\hline 43 & Male & 63 & Peripheral & I & $20 \times 43$ & Farmer \\
\hline
\end{tabular}

(population 12.7 million) is comprised of many islands. Niigata (population 24.7 million) is located on the Sea of Japan and includes a big island. Thirty cases of SCC of the lung from Niigata University Hospital, all of which came to surgery in 1993, were also examined. The total number (87 cases) of lung carcinoma in Niigata University were classified as follows: adenocarcinoma $n=43$; squamous cell carcinoma $n=30$; large cell carcinoma $n=$ 5 ; small cell carcinoma $n=5$; carcinoid tumour $\mathrm{n}=2$; and pulmonary blastoma $\mathrm{n}=2$.

Almost all of the patients in Okinawa were operated on for lung cancer in the National Okinawa Hospital and Ryukyu University Hospital. Nearly all of the patients with lung cancer from Niigata were operated on in Niigata University hospitals. Not all patients (Okinawa and Niigata) had been treated with radiation or chemotherapy before surgery. The number of deaths from malignant neoplasm of the trachea, bronchus, and lung (age ajusted mortality/100 000 population $)^{2}$ in Okinawa is the highest in Japan at 28.5 for men and 16.8 for women. Comparable figures for Niigata are 21.4 for men and 11.9 for women.

Most of the patients in the study were farmers or fishermen. There were no miners or heavy industry workers in Okinawa and Niigata (tables 1 and 2).
Ten cases (five from National Okinawa Hospital and five from Ryukyu University Hospital) of adenocarcinoma of the lung (six of bronchioloalveolar type and four of ductal type), and normal necropsy lung samples, six cases of adenosquamous carcinoma of the lung, one each of small cell carcinoma and large cell carcinoma (from National Okinawa Hospital) served as controls, as did cultured HeLa cells (from the Japanese Cancer Research Resource Bank, Setagaya-ku Tokyo, Japan). Distilled water was also used as negative control in the PCR detection of HPV.

\section{HISTOLOGICAL EXAMINATION AND NISH}

Samples were fixed in $10 \%$ phosphate buffered formalin and examined routinely. The techniques used for sample processing and examination were the same among the three hospitals (National Okinawa Hospital, Ryukyu University Hospital, and Niigata University Hospital). Haematoxylin and eosin, Gomori's silver impregnation, periodic acid Schiff and alcian blue staining were performed on $4 \mu \mathrm{m}$ dewaxed sections. The histological specimens were examined by one pathologist (TH).

Non-isotopoic in situ hybridisation (NISH) was performed on all specimens from Okinawa and Niigata. Using HPV 6/11, 16/18, and $31 / 33 / 51$ biotin labelled probes from the 
Table 2 Demographic details of patients with squamous cell carcinoma of the lung from Niigata

\begin{tabular}{|c|c|c|c|c|c|c|}
\hline Case & Sex & Age & Location & Stage & $\begin{array}{l}\text { Tobacco smoking } \\
\text { (numbers/days } \times \text { years) }\end{array}$ & Occupation \\
\hline 1 & Male & & Central & I & $?$ & Secretary \\
\hline 2 & Male & & Central & I & $20 \times 63$ & Farmer \\
\hline 3 & Male & & Central & IIIb & $30 \times 54$ & Fisherman \\
\hline 4 & Male & & Central & 0 & $40 \times 52$ & Farmer \\
\hline 5 & Male & & Central & II & $50 \times 50$ & Shopkeeper \\
\hline 6 & Male & & Central & IIIa & $?$ & Farmer \\
\hline 7 & Male & & Central & 0 & $?$ & Shopkeeper \\
\hline 8 & Male & & Central & II & $?$ & $?$ \\
\hline 9 & Male & & Central & I & $?$ & Fisherman \\
\hline 10 & Male & & Central & I & $20 \times 40$ & Government employee \\
\hline 11 & Male & & Central & IIIa & $25 \times 35$ & $?$ \\
\hline 12 & Male & & Central & IV & $20 \times 30$ & Engineer \\
\hline 13 & Male & & Central & IIIb & $35 \times 36$ & Express company \\
\hline 14 & Male & & Peripheral & IIIa & $25 \times 60$ & Government employee \\
\hline 15 & Male & & Peripheral & I & $20 \times 49$ & Consultant on economic affairs \\
\hline $16^{\star}$ & Male & & Peripheral & I & $20 \times 50$ & $?$ \\
\hline 17 & Male & & Peripheral & I & $15 \times 50$ & Secretary \\
\hline 18 & Male & & Peripheral & I & $?$ & $?$ \\
\hline 19 & Male & & Peripheral & II & ? & $?$ \\
\hline 20 & Male & & Peripheral & I & $20 \times 40$ & Farmer \\
\hline 21 & Female & & Peripheral & I & 0 & Housewife \\
\hline 22 & Male & & Peripheral & I & $20 \times 50$ & $?$ \\
\hline $23^{\star}$ & Male & & Peripheral & I & $20 \times 50$ & $?$ \\
\hline 24 & Male & & Peripheral & IIIa & $20 \times 40$ & Secretary \\
\hline 25 & Male & & Peripheral & I & $?$ & Farmer \\
\hline 26 & Male & & Peripheral & IIIa & $?$ & $?$ \\
\hline 27 & Male & & Peripheral & I & $20 \times 47$ & Engineer \\
\hline 28 & Male & & Peripheral & IIIa & ? & ? \\
\hline $29^{\star}$ & Male & & Peripheral & I & $20 \times 43$ & Engineer \\
\hline $30^{\star}$ & Male & & Peripheral & IIIb & $20 \times 43$ & Engineer \\
\hline
\end{tabular}

${ }^{\star}$ Cases $16,23,29$, and 30 were classified as multiple primary carcinoma of the lung, according to the criteria of Warren and Gates. ${ }^{14}$

ENZO pathoGene in situ HPV tissue hybridisation kit (New York, USA), NISH was carried out according to the method of Cooper et al ${ }^{15}$ and the manufacturer's instructions. After unmasking with proteinase $\mathrm{K}$ (Merck, Tokyo, Japan) at a concentration of $2 \mu \mathrm{g} / \mathrm{ml}$ in $50 \mathrm{mM}$

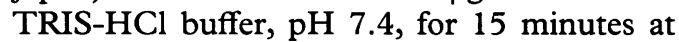
$37^{\circ} \mathrm{C}$, NISH was carried out using biotin labelled probe DNA. The sections were incubated with prehybridisation solution containing $2 \times$ SSC (sodium saline citrate), $\mathrm{pH}$ $7.2,10 \%$ dextran sulphate (w/v), $400 \mu \mathrm{g} / \mathrm{ml}$ of sonicated herring sperm DNA and $50 \%$ formamide $(\mathrm{v} / \mathrm{v})$. Denaturation of probe and target DNA in the sections was perfomed simultaneously on the hot plate $\left(90^{\circ} \mathrm{C}\right)$ for two minutes. Hybridisation was subsequently carried out using $1 \mathrm{~g} / \mathrm{ml}$ biotinylated HPV DNA by incubating the sections overnight in a humidified chamber at $37^{\circ} \mathrm{C}$. Biotin was detected using peroxidase labelled streptavidin. $\mathrm{H}_{2} \mathrm{O}_{2}$ and DAB (3,3'diaminobenzidine) were used for the peroxidase reaction.

DETECTION OF HPV TYPES 6, 11, 16 AND 18 DNA BY PCR

DNA samples from the 43 cases of SCC from Okinawa and 30 cases from Niigata were prepared according to the methods described by Impraim et al. ${ }^{16} \mathrm{Within}$ three to four weeks of obtaining samples, 30 paraffin wax sections of $10 \mu \mathrm{m}$ thickness were placed in $15 \mathrm{ml}$ tubes. The paraffin wax was removed by washing twice in $10 \mathrm{ml}$ of xylene for 30 minutes each and in $100 \%$ ethanol for 30 minutes, twice. Then the specimens were digested with proteinase $\mathrm{K}$ (Wako Co., Chuo-ku, Osaka, Japan) in $500 \mathrm{mM}$ TRIS-HCl buffer, $\mathrm{pH}$ 7.5, containing $0.45 \%$ Tween 20 and $2.5 \mathrm{mM} \mathrm{MgCl}_{2}$ at $37^{\circ} \mathrm{C}$ for 36 hours. The DNA was extracted using phenol/chloroform twice (the former equilibrated with $1 \mathrm{M}$ TRIS-HCl, $\mathrm{pH} 8.0$, containing $0.1 \%$ quinolinol and the latter a $24: 1(\mathrm{v} / \mathrm{v})$ mixture of chloroform and isoamylalchol), then once more with chloroform. The DNA was precipitated with three times the volume of $100 \%$ ethanol containing $0.1 \mathrm{M}$ sodium acetate at $-20^{\circ} \mathrm{C}$. DNA was used for PCR immediately after the extraction. The 110 base pair $\beta$-globin gene was detected (data not shown) in all DNA samples extracted from each case by PCR, according to the method of Saiki et $a l^{17}$ using their primers (PCO3 and PCO4).

The primers and probes for HPV 16 and 18 E7 used in this experiment are as follows:

\section{HPV 16 E7}

Primer (sense): 5'-CCAGAGACAACTGATCTCTAC-3'; primer (antisense): 5'-GTGTGTGCTTTGTACGCACAAC-3'; probe: 5'-TAACCTTTTGTTGCAAGTGTGACTCTACGCTTCG-3'.

A 171 base pair PCR product is obtained.

\section{HPV 18 E7}

Primer (sense): 5'-GAGCCGAACCACAACGTCAC-3'; primer (antisense): 5'-GGATGCACACCACGGACACA-3'; probe: 5'-TCCAGCAGCTGTTTCTGAACACCCTG-3'.

A 152 base pair PCR product is obtained.

The primers for E6 regions of HPV 6, 11, 16 and 18 and probes for Southern and dot blot analysis were the same as those reported by McNicol et al. ${ }^{18}$

\section{HPV 6 E6}

Primer (sense): 5'-GCTGGATATGCAA-CAA CAGTTG-3'; primer (antisense): 5'-CA-TGC- 
ATGTTGTCCAGCAGTG-3'; probe: 5'-GCTACCTGTGTCACAAACCG-3'.

A 189 base pair PCR product is obtained.

HPV 11 E6

Primer (sense): 5'-GCAGCGTGTGCCTG-TTGCTTA-3'; primer (antisense): 5'-AAG-CAACGACCCTTCCACTGG-3'; probe: 5'-CCTGTGTCACAAGCCGTTGTG-3'.

A 230 base pair PCR product is obtained.

HPV 16 E6

Primer (sense): 5'-GATGGGAATCCATATGCTGTA-3'; primer (antisense): 5'-TCGACCGGTCCACCGACCCCT-3'; probe: 5'-GCCACTGTGTCCTGAAGAAAAGC-3'.

A 240 base pair PCR product is obtained.

\section{HPV 18 E6}

Primer (sense): 5'-CAGTATACCCCATGCTGCATGCC-3'; primer (antisense): 5'-CGGTTTCTGGCACCGCAGGCACC-3'; probe: 5'-CAGACTCTGTGTATGGAGACAC-3'.

A 160 base pair PCR product is obtained.

The PCR reaction mixture contained 10 $\mathrm{mM}$ TRIS- $\mathrm{HCl}, \mathrm{pH} 8.3,50 \mathrm{mM} \mathrm{KCl}, 1.5 \mathrm{mM}$ $\mathrm{MgCl}_{2}, 0.01 \%$ gelatin, $0.4 \mathrm{mM}$ each of 4 dNTPs, $0.32 \mu \mathrm{g}$ each primer and 2.5 units of Taq DNA polymerase (Cetus-Takara, Seta, Otsu, Japan). Reaction conditions were as follows: annealing at $62^{\circ} \mathrm{C}$ for three minutes, denaturation at $94^{\circ} \mathrm{C}$ for two minutes, and extension at $74^{\circ} \mathrm{C}$ for four minutes for 40 cycles. The amplified DNA was transferred on to nylon membranes (Hybond-N+, Amersham Life Science, Buckinghamshire, UK) after routine polyacrylamide gel $(10 \%)$ electrophoresis, and using a probe and Amersham's system (Amersham's ECL 3'-oligolabelling and detection system), Southern blot analysis was carried out according to the instructions provided by Amersham Life Science. For dot blot analysis, the amplified DNA samples were immobilised on a nylon membrane (Hybond$\mathrm{N}+$, Amersham Life Science) and detected with the same probe used for Southern blot analysis. The sensitivity of the PCR method was tested using various concentrations of

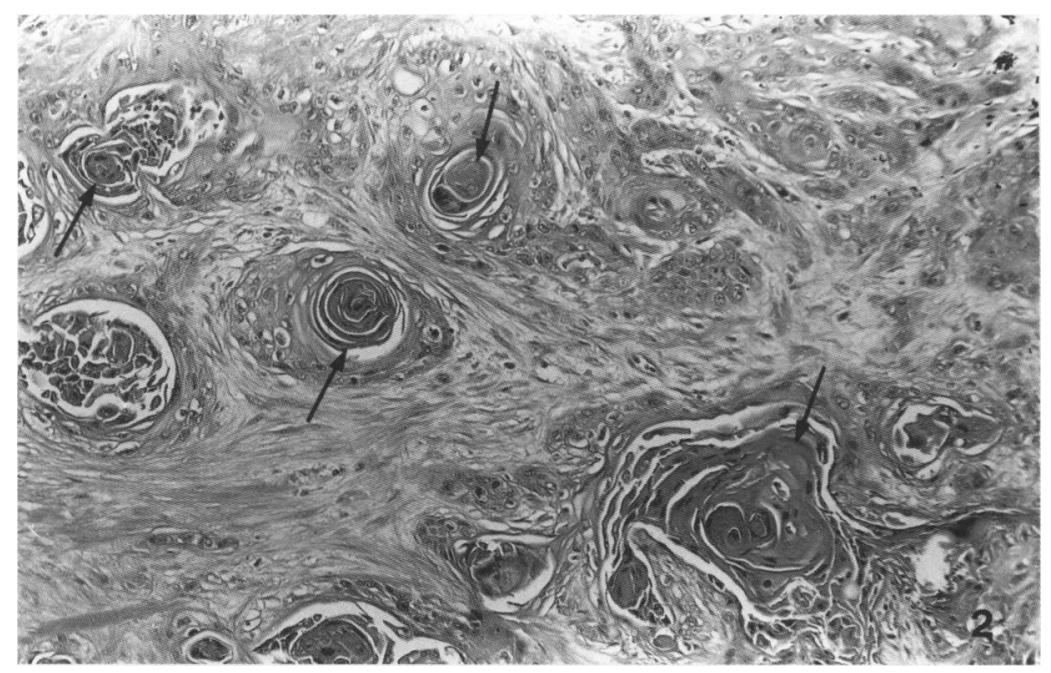

Figure 1 Well differentiated squamous cell carcinoma of the lung. Okinawan case 1. Arrows indicate keratin pearls. (Haematoxylin and eosin.)
HPV 11, 16, and 18 DNA in plasmid pBR 322 and HPV 6 in plasmid pML, which were obtained from the Japanese Cancer Research Resource Bank, with permission from Dr Zur Hausen.

Statistical analysis was performed using the Mantel-Haentzel $\chi^{2}$ method, and multiple regression analysis (Statistical Analysis System, SAS Institute Inc., Cary, North Carolina, USA). The level of significance was set at $\mathrm{p}<$ 0.05 .

The PCR products of the HPV 18 E6 and E7 regions were extracted from the agarose gel. The extracted DNA was cloned into the pGEM-T vector (Promega, Madison, Wisconsin, USA) according to the manufacturer's instructions. The sequence reaction was carried out using the Sanger dideoxynucleotide method. ${ }^{19} 20$ The sequences obtained from our samples were compared with the prototype HPV 18 E6 and E7 region sequences. ${ }^{21}$

\section{Results}

Twenty eight $(65.1 \%)$ cases of Okinawan squamous cell carcinoma were well differentiated with keratin pearl formation and intercellular bridges (fig 1, table 3). Thirteen and two cases in the sample group were moderately and poorly differentiated (without keratin pearl) types, respectively. Table 1 shows that the mean (SD) age of the patients was 68.3 (8.6) years; 39 were male and four female. Thirty four $(79 \%)$ cases were stage I, two $(4.7 \%)$ were stage 0 , and seven $(16.3 \%)$ were stages II-IV. In 18 cases tumours were centrally located and peripheral in 25 . Koilocytotic cells were observed in 13 cases of well, and three cases of moderately, differentiated carcinomas. There were no such cells in the two poorly differentiated cases.

In Niigata, there were only three cases of well differentiated carcinoma; poorly differentiated cases (fig 2) accounted for $50 \%$ (15 cases) of the total (table 4). Koilocytotic cells were found in three of the well and two of the moderately differentiated cases. The mean (SD) age of the patients was $68.1(8.6)$; one was female. Thirteen $(43 \%)$ cases were centrally located, and the rest were peripheral. Fifteen $(50 \%)$ cases were stage I, two $(7.1 \%)$ were stage 0 , and the remaining $13(43 \%)$ were stages II-IV. Most of the Niigata and Okinawan patients were heavy smokers. In Niigata, only one woman (case 21 in table 2) was a non-smoker, and among the Okinawan cases, one woman (case 35 in table 1) was not a heavy smoker. There was no correlation between the degree of smoking and the histological differentiation of the carcinoma by multiple regression analysis.

In Niigata the number of well differentiated carcinomas was significantly smaller than that of moderately or poorly differentiated types.

There was a significantly high proportion of cases of well differentiated type in Okinawa $(\mathrm{p}<0.001)\left(\chi^{2}\right.$ analysis $)$.

Using in situ hybridisation, we found HPV $6 / 11$ in seven of well, and two of moderately, differentiated, squamous cell carcinoma and HPV $16 / 18$ in 13 of well, and eight of 
Table 3 Histological differentiation and detection of HPV in patients with squamous cell carcinoma of the lung from Okinawa

\begin{tabular}{|c|c|c|c|}
\hline Case & Histological differentiation & $\begin{array}{l}\text { Detection of } H P V \text { by } P C R \text {. Type of } H P V \\
\text { (E6 andlor E7 region) }\end{array}$ & $\begin{array}{l}\text { Detection of HPV by NISH. } \\
\text { Type of signal and HPV }\end{array}$ \\
\hline 1 & Well & $16(\mathrm{E} 6)$ & - \\
\hline 2 & Well & 16 (E6) 18 (E7) & Type 3 (HPV16/18) \\
\hline 3 & Well & $16(\mathrm{E} 7)$ & - \\
\hline 4 & Well & 16 (E7) 18 (E7) & Type 3 (HPV16/18) \\
\hline 5 & Well & $18(\mathrm{E} 6, \mathrm{E} 7)$ & - \\
\hline 6 & Well & 16 (E6) $18(\mathrm{E} 6, \mathrm{E} 7)$ & Type 3 (HPV16/18) \\
\hline 7 & Well & 6 (E6) $16(\mathrm{E} 6, \mathrm{E} 7) 18(\mathrm{E} 6, \mathrm{E} 7)$ & Type 3 (HPV6/11), type 3 (HPV16/18) \\
\hline 8 & Well & 16 (E6) 18 (E7) & Type 3 (HPV16/18) \\
\hline 9 & Well & $16(\mathrm{E} 6, \mathrm{E} 7)$ & - \\
\hline 10 & Well & 6 (E6) 18 (E7) & Type 3 (HPV6/11), type 3 (HPV16/18) \\
\hline 11 & Well & - & - \\
\hline 12 & Well & $18(\mathrm{E} 7)$ & - \\
\hline 13 & Well & $16(\mathrm{E} 6, \mathrm{E} 7) 18(\mathrm{E} 7)$ & Type $2(\mathrm{HPV} / 18)$ \\
\hline 14 & Moderately & 16 (E6) 18 (E7) & - \\
\hline 15 & Moderately & - & - \\
\hline 16 & Moderately & 16 (E6) $18(\mathrm{E} 6, \mathrm{E} 7)$ & Type 3 (HPV16/18) \\
\hline 17 & Moderately & 16 (E6) 18 (E6) & Type 3 (HPV16/18) \\
\hline 18 & Moderately & 16 (E6, E7) 18 (E7) & Type 3 (HPV16/18) \\
\hline 19 & Well & 6 (E6) & - \\
\hline 20 & Well & - & - \\
\hline 21 & Well & $16(\mathrm{E} 6)$ & - \\
\hline 22 & Well & $18(\mathrm{E} 7)$ & - \\
\hline 23 & Well & 16 (E7) $18(\mathrm{E} 7)$ & Type 3 (HPV16/18) \\
\hline 24 & Well & $16(\mathrm{E} 6, \mathrm{E} 7) 18(\mathrm{E} 6, \mathrm{E} 7)$ & Type 3 (HPV16/18) \\
\hline 25 & Well & $16(\mathrm{E} 6, \mathrm{E} 7) 18(\mathrm{E} 6, \mathrm{E} 7)$ & Type 3 (HPV16/18) \\
\hline 26 & Well & - & - \\
\hline 27 & Well & 6 (E6) $16(\mathrm{E} 7) 18(\mathrm{E} 7)$ & Type 3 (HPV6/11), type 3 (HPV16/18) \\
\hline 28 & Well & 6 (E6) 16 (E6, E7) 18 (E6, E7) & Type 3 (HPV6/11), type 3 (HPV16/18) \\
\hline 29 & Well & 6 (E6) $16(\mathrm{E} 6, \mathrm{E} 7) 18(\mathrm{E} 6, \mathrm{E} 7)$ & Type 3 (HPV6/11), type 3 (HPV16/18) \\
\hline 30 & Well & - & - \\
\hline 31 & Well & 6 (E6) 16 (E7) & Type 3 (HPV6/11) \\
\hline 32 & Well & - & - \\
\hline 33 & Well & $6(\mathrm{E} 6)$ & Type 1 (HPV6/11) \\
\hline 34 & Moderately & - & - \\
\hline 35 & Moderately & $18(\mathrm{E} 7)$ & Type 2 (HPV16/18) \\
\hline 36 & Moderately & 18 (E7) & Type 3 (HPV 16/18) \\
\hline 37 & Moderately & 16 (E7) 18 (E6) & Type 3 (HPV16/18) \\
\hline 38 & Moderately & 6 (E6) 18 (E7) & Type 3 (HPV6/11), type 3 (HPV16/18) \\
\hline 39 & Moderately & 6 (E6) $16(\mathrm{E} 6, \mathrm{E} 7) 18(\mathrm{E} 6, \mathrm{E} 7)$ & Type 3 (HPV6/11), type 3 (HPV16/18) \\
\hline 40 & Moderately & 16 (E7) & - \\
\hline 41 & Moderately & 6 (E6) 16 (E7) & - \\
\hline 42 & Poorly & - & - \\
\hline 43 & Poorly & - & - \\
\hline
\end{tabular}

PCR = polymerase chain reaction; NISH = non-isotopic in situ hybridisation by use of commercially available probes, HPV6/11, HPV16/18 and HPV31/33/51. According to Cooper's criteria, ${ }^{15}$ positive signals were classified as type 1 , type 2 and type 3 . The physical states of the virus: type 1 signal, episomal HPV; type 2 signal, integrated HPV; and type 3 signal, episomal and integrated HPV.

moderately, differentiated cases in Okinawa (fig 3). Five of well and two of moderately differentiated cases positive for HPV 6/11 were also positive for HPV $16 / 18$. Twenty three Okinawan cases (53\%) were positive for HPV by in situ hybridisation (table 3). In Niigata HPV $16 / 18$ was also shown in two moderately

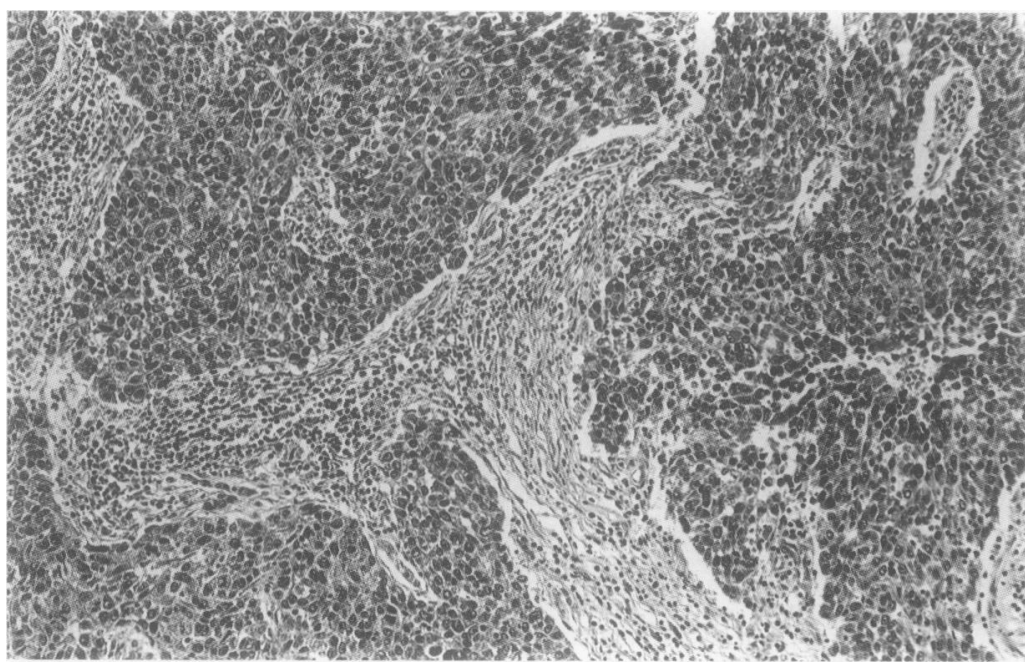

Figure 2 Poorly differentiated squamous cell carcinoma of the lung (Niigata case 8). There are no keratin pearls, but small foci of keratinisation are occasionally seen. (Haematoxylin and eosin.) and four poorly differentiated cases (20\%) (table 4). These cases were also positive for HPV DNA by PCR. The presence of HPV by in situ hybridisation was discovered mainly on the nuclei of koilocytotic cells. According to 음 Cooper's criteria, ${ }^{15}$ NISH type 3 signals (episo- $D$ mal and integrated HPV) were frequently observed on Okinawan and Niigata cases (fig $N$ 3 , tables 3 and 4). Two cases (cases 13 and 35 in table 3 ) showed the type 2 signal (integrated HPV) and only one case (case 33 in table 3) the type 1 signal (episomal HPV). No positive signal for HPV 31/33/51 was shown in any of the Okinawan and Niigata cases. A positive signal was not shown on adenocarcinomas, small cell carcinoma, large cell carcinoma and mucoepidermoid carcinoma. But type 3 signals were demonstrated on the squamous cell carcinoma regions in four cases of adenosquamous carcinoma. Two cases of adenosquamous carcinoma were negative for HPV by NISH.

DETECTION OF HPV $6,11,16,18$ DNA BY PCR Using Southern blot analysis with chemiluminescence (Amersham Life Science) probes, a lower limit of 100 and 134 viral copies of the HPV 16 and 18 E7 regions, respectively, was detected. In the cases of HPV 6, 11, 16 and 18 
Table 4 Histological differentiation and detection of HPV in patients with squamous cell carcinoma of the lung from Niigata

\begin{tabular}{|c|c|c|c|}
\hline Case & $\begin{array}{l}\text { Histological } \\
\text { differentiation }\end{array}$ & $\begin{array}{l}\text { Detection of HPV by PCR. Type } \\
\text { of } H P V \text { (E6 and/or E7 region) }\end{array}$ & $\begin{array}{l}\text { Detection of HPV by NISH. } \\
\text { Type of signal and HPV }\end{array}$ \\
\hline 1 & Well & - & - \\
\hline 2 & Well & - & - \\
\hline 3 & Moderately & - & - \\
\hline 4 & Moderately & - & - \\
\hline 5 & Moderately & 16 (E7) & - \\
\hline 6 & Moderately & - & - \\
\hline 7 & Moderately & - & - \\
\hline 8 & Poorly & 18 (E7) & Type 3 (HPV16/18) \\
\hline 9 & Poorly & - & - \\
\hline 10 & Poorly & - & - \\
\hline 11 & Poorly & - & - \\
\hline 12 & Poorly & 18 (E7) & Type 3 (HPV16/18) \\
\hline 13 & Poorly & - & - \\
\hline 14 & Well & - & - \\
\hline 15 & Moderately & - & - \\
\hline $16^{\star}$ & Moderately & $18(\mathrm{E} 7)$ & Type 3 (HPV16/18) \\
\hline 17 & Moderately & - & - \\
\hline 18 & Moderately & - & - \\
\hline 19 & Moderately & - & - \\
\hline 20 & Moderately & - & - \\
\hline 21 & Moderately & $16(\mathrm{E} 7)$ & - \\
\hline 22 & Poorly & 18 (E7) & Type 3 (HPV16/18) \\
\hline $23^{\star}$ & Poorly & 18 (E7) & Type 3 (HPV16/18) \\
\hline 24 & Poorly & - & - \\
\hline 25 & Poorly & $18(\mathrm{E} 7)$ & - \\
\hline 26 & Poorly & 18 (E7) & Type 3 (HPV16/18) \\
\hline 27 & Poorly & - & - \\
\hline 28 & Poorly & - & - \\
\hline $29 \star$ & Poorly & - & - \\
\hline $30^{\star}$ & Poorly & - & - \\
\hline
\end{tabular}

PCR = polymerase chain reaction; NISH = non-isotopic in situ hybridisation by use of commercially available probes, HPV6/11, HPV16/18 and HPV31/33/51. According to Cooper's criteria, ${ }^{15}$ positive signals were classified as type 1 , type 2 and type 3 . The physical states of the virus: type 1 signal, episomal HPV; type 2 signal, integrated HPV; and type 3 signal, episomal and integrated HPV. ${ }^{\star}$ Cases $16,23,29$, and 30 were classified as multiple primary carcinoma of the lung, according to the criteria of Warren and Gates. ${ }^{14}$

E6, using McNicol's primers and probes, a lower limit of 153, 1335, 100 and 13400 viral copies was detected, respectively. The sensitivities of PCR using these various primers and probes varied. Cases where either one or both of the E6 and E7 regions were detected, were counted as positive for HPV DNA. Thirty four cases $(79.1 \%)$ in Okinawa were positive for HPV DNA by PCR (table 3) (figs 4A and 5A), of which 18 cases were positive for both HPV 16 and 18, and five were positive for HPV 6, 16 , and 18. No such dual or triple presence was found in the Niigata cases.

Seventeen well and eight moderately differentiated cases in Okinawa were positive for

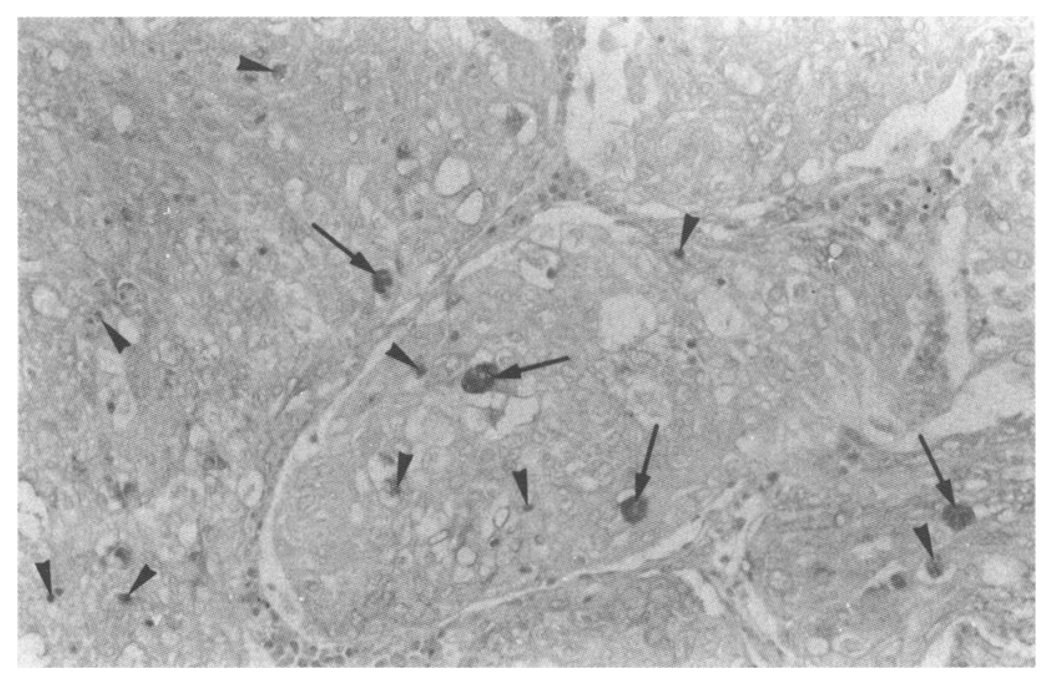

Figure 3 HPV DNA detected by non-isotopic in situ hybridisation (Okinawan case 2). 15 NISH signal type 3-that is, both episomal (arrows) and integrated (arrowheads) HPV.
HPV 16, and 11 cases (eight of which were well and two moderately differentiated) were positive for HPV 6. HPV 6 DNA was also detected in seven HPV 16 positive cases. A total of 29 cases were positive for HPV 16 and/or 6 . Two of the in situ carcinoma cases (stage 0 ) (cases 3 and 6) were also positive for HPV 16 . HPV 18 was shown in 25 Okinawan cases, of which 13 well and seven moderately differentiated cases were dual or triple positive for HPV 6 and/or 16. Only five cases - three well and two moderately differentiated types-were positive for HPV 18 DNA alone. No HPV DNA was detected in two of the poorly differentiated cases and in the 10 cases of adenocarcinoma, 10 normal lung samples, one each of small cell carcinoma, large cell carcinoma, and mucoepidermoid carcinoma, and two adenosquamous carcinoma of the lung. HPV 18 was detected on HeLa cells. HPV 6, 16, and 18 (triple positive) were detected in squamous cell carcinoma regions of adenosquamous carcinoma (four cases).

In Niigata seven cases were just positive for HPV 18, six of which were poorly differentiated carcinomas (table 4 ) (figs $4 B$ and $5 B$ ).

HPV 16 was shown in only two cases of moderately differentiated carcinoma. HPV 6 was not detected in any of the Niigata cases (data not shown). Nine cases $(79.1 \%)$ were positive for HPV.

HPV 11 was not shown in any of the Okinawan and Niigata cases. HPV DNA was detected in a significantly higher number of cases in Okinawa than in Niigata $(p<0.001$; $\chi^{2}$ test). HPV DNA was frequently shown in well differentiated squamous cell carcinoma ( $p$ $<0.05$ ) using the $\chi^{2}$ and multiple regression analysis. Detection of HPV type 6 ( $p<0.035)$ and $16(\mathrm{p}<0.001)$ was associated with well differentiated type, but there was no such association with the detection of HPV 18 . There was, however, an association between HPV 18 and poorly differentiated type ( $p<$ $0.032)$ in Niigata $\left(\chi^{2}\right.$ analysis). No significant correlation was found between detection of HPV DNA and the degree of smoking by multiple regression analysis.

No sequence variation was noted in the HPV 18 DNA of the PCR products from either region (E6 and E7) (data not shown) compared with the published sequences. ${ }^{21}$

\section{Discussion}

In general, well differentiated squamous cell carcinoma of the lung is now relatively rare. ${ }^{478}$ In Okinawa there is a high incidence of this type of squamous cell carcinoma of the lung. Although smoking and other environmental factors are important carcinogens, no significant correlation between the degree of smoking and histological differentiation was found. On the other hand, PCR showed that $79 \%$ of Okinawan cases were HPV positive, a much higher proportion than in Niigata. In Niigata only $30 \%$ of the cases were positive for HPV. The rate in Niigata was similar to that in other reports. ${ }^{1011}$ NISH showed that $53 \%$ of Okinawan and $20 \%$ of Niigata cases were positive for HPV. Most of the HPV positive cases in 
Okinawa and Niigata showed type 3 signal
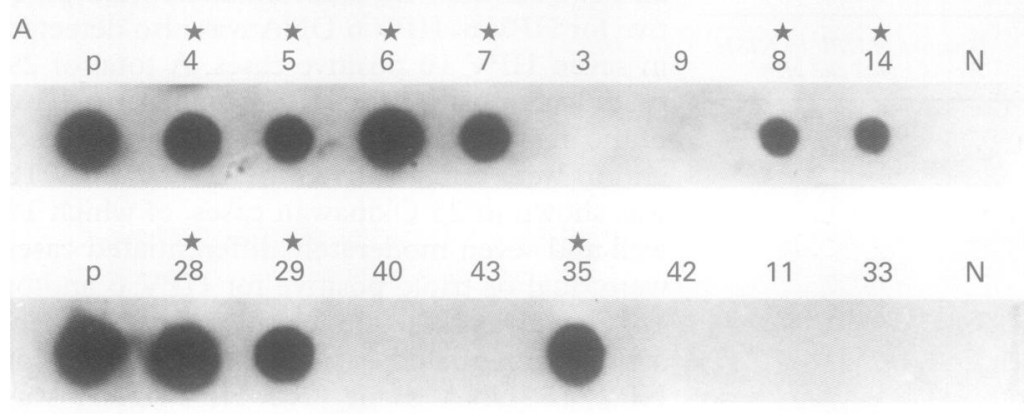

B
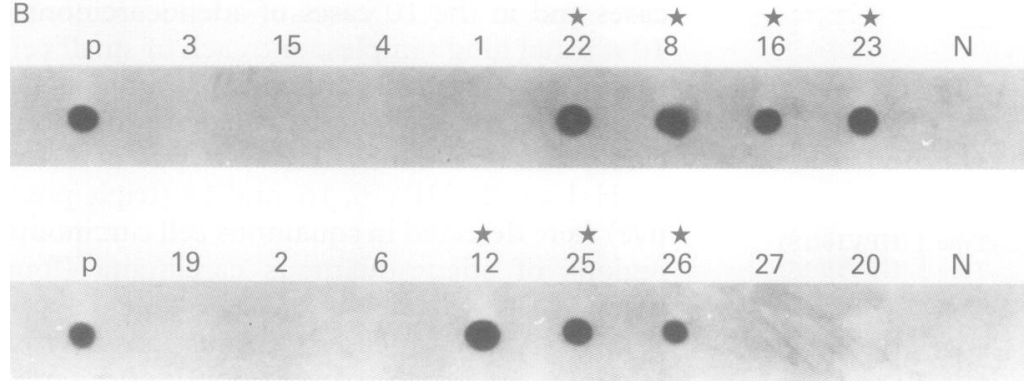

Figure 4 (A) Dot blot analysis of PCR product (HPV 18 E7 region). Okinawan cases (cases $4,5,6,7,8,14,28,29$ and $35^{\star}$ ) are positive; reference numbers are those used in tables 1 and 3. $p=$ positive control (HPV 18 in plasmid $p B R 322), N=$ negative control (normal lung). (B) Dot blot analysis of PCR product (HPV 18 E7 region), Niigata cases (cases 22, 8, 16, 23, 12, 25 and 26*) are positive cases; reference numbers are those used in tables 3 and $4 . p=$ positive control (HPV 18 in plasmid $p B R 322) ; N=$ negative control (normal lung).

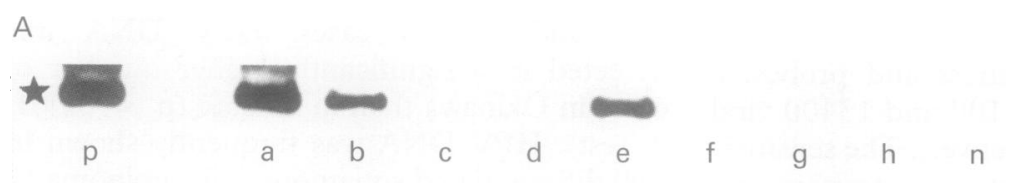

B

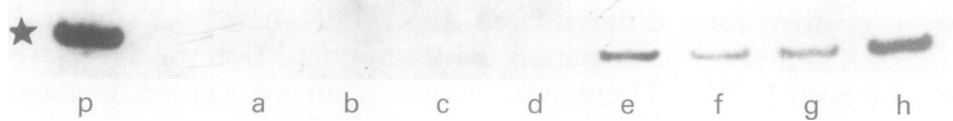

Figure 5 (A) Demonstration of HPV 16 E7 region by PCR in Okinawan cases; Southern blot analysis. Lanes $a, b, c, d, e, f, g$ and $h$ are cases $3,4,1,2,31,33,34$ and 42 (table 1), respectively. 171 base pair bands $\left({ }^{\star}\right)$ are demonstrated in lanes $a, b, e$ and $p . n=$ negative control (adenocarcinoma); $p=$ positive control (1 pg of HPV DNA). (B) Demonstration of HPV 18 E7 region by PCR in Niigata cases; Southern blot analysis. Lanes $a, b, c, d, e, f, g$ and $h$ are cases $1,2,3,4,8,12,16$ and 25 (table 2), respectively; 152 base pair bands $\left(^{*}\right)$ are shown in lanes $e, f, g$, and $h . n=$ negative control (adenocarcinoma in Okinawa); $p=$ positive control (1 pg of HPV in plasmid pBR 322).

which indicated the combination of the episomal and integrated forms of HPV. Only one well differentiated Okinawan case showed the type 1 signal (episomal HPV) of HPV 6/11.

On the other hand, Shamanin et $a l^{22}$ have reported that none of 85 cases of lung cancer biopsy specimens was positive for HPV by PCR when detecting the $\mathrm{Ll}$ and E1 open reading frames. These open reading frames might be disrupted following integration of $\mathrm{HPV}$ into the human genome.

There are many reports about HPV and its role in carcinogenesis in uterine cervical carcinoma. ${ }^{18}$ 23-30 Certain specific HPV types have been reported to be associated with either low grade (HPV 6, 11, 42, 44) or high grade squamous intraepithelial lesions and carcinoma of the uterine cervix (HPV 16, 18, etc.).
Other HPV types, such as $31,33,35,51,52$ and 58 are considered to be intermediate risk types. ${ }^{30} \mathrm{HPV} 16$ and 18 are frequently found in invasive carcinoma of the uterine cervix. Episomal HPV (type 1 signal) is often found in CIN II (cervical intraepithelial neoplasia II). The integrated or a combination of episomal and integrated HPV (types 2 or 3 signals) were demonstrated in CIN III and squamous cell carcinoma. ${ }^{15}$ In this study we concentrated on the detection of HPV 16 and 18, which are known to be high risk types and are associated with histological differentiation of carcinoma. HPV 6 and 11, which have been associated with keratinising verrucous lesions of the skin, were also looked for. The primers specific for E6 and E7 lesions, which are preserved in HPV associated squamous cell carcinoma, were used.

It is also reported that the detection of HPV DNA is significantly associated with the well $\overrightarrow{0}$ differentiated carcinoma, particularly HPV $16 \vec{\circ}$ and 6 , which results in the keratinisation of the lesions. ${ }^{26} \mathrm{HPV} 16$ and 18 DNA were frequently $\vec{\circ}$ detected in the Okinawan cases. On the other hand, a positive association between HPV 18 DNA and histological differentiation, in the Okinawa and Niigata cases was not shown. If the Niigata cases only are considered, then detection of HPV 18 DNA was associated with the poorly differentiated type. However, three cases of well differentiated carcinoma in Okinawa were positive for only HPV 18 DNA. HPV 18 has been reported to have an aetiological role in poorly differentiated squamous cell carcinoma of the uterine cervix. ${ }^{23}$ It is thought that small differences in the HPV 18 DNA sequence of the transforming regions within the HPV could alter its effects on HPV infectivity and cancer morphology. ${ }^{24}$ No such sequence variation was noted in the HPV 18 DNA of the PCR products. The sequence analysis of other regions of HPV 18 DNA in Okinawan cases is needed to reach a definitive conclusion. HPV DNA was not detected in all cases of adenocarcinoma, small, and large cell carcinoma. On the other hand, four of six cases of adenosquamous carcinoma were positive for HPV DNA. NISH showed type 3 signals on the lesions of squamous cell carcinoma in adenosquamous carcinoma, but not on the adenocarcinoma. It was therefore considered that the squamous cell differentiation might be related to HPV infection.

Okinawa consists of many islands located in the southernmost part of Japan $(1600 \mathrm{~km}$ from Tokyo), and lies in the subtropical climatic zone. The subtropical temperature, high humidity, and slightly lower economic activity might influence the rate of HPV infection. Cervical carcinoma was also more frequently observed in Okinawa than in mainland Japan. ${ }^{1}$ More than 100 years ago Okinawa was an independent kingdom. A study of serum $\mathrm{Gm}$ allotypes have shown the similarity of Okinawan people to mainland Japanese, ${ }^{31}$ but minor differences have also been reported from the seroanthropological viewpoint. It is still unclear whether host factors could influence susceptibility to HPV and/or cancer morphology. 
The association between HLA and HPV infection is under discussion. ${ }^{32-35}$

We conclude, however, that the histological differentiation of squamous cell carcinoma of the lung, especially well differentiated carcinoma in Okinawa, is closely associated with HPV DNA. It is still unclear whether HPV infection occurs before or after the tumour has developed. Two cases of Okinawan in situ carcinoma were positive for HPV DNA. Therefore, HPV might be associated with the early stage of tumour development. Double or triple infection with HPV 6, 16, and 18 might occur after the tumour has developed. HPV 6, a low risk type HPV, might be superimposed on HPV 16 and/or 18 positive cancers and might influence the histological differentiation of the squamous cell carcinoma. Further study of squamous cell carcinoma of the lung and detection of HPV in Okinawa after five, 10, or 20 years may help to elucidate this.

We thank Dr Hidemi Todoriki, Department of Hygiene and Public Health, and Dr Yorio Kimura, Department of Interna Medicine, Ryukyu University School of Medicine, for help in the statistical analysis of the data.

1 Okinawa Prefecture. Annual statistical report on health and environment. Okinawa: Okinawa Prefectural Government, 1993:13-82.

2 Statistics and Information Department. Malignant neoplasm of trachea, bronchus and lung. In: Age Adjusted Death Rates from Malignant Neoplasms by Site, each Prefecture. Tokyo: Ministry of Health and Welfare of Japan, 1991:1-8.

3 Iwamasa T, Hirayasu T, Genga K. Carcinoma of the lung in Okinawa. Report of Epidemiological Study of the Diseases in Okinawa. Okinawa: Ryukyu University School of Medicine, 1995:11-19.

4 Saldana MJ, Nones JM. Squamous cell carcinoma. In: Saldana MJ, ed. Pathology of pulmonary disease. Philadelphia: JB Lippincott, 1994:545-54.

5 Miyaji T. Histopathologic examination of 1152 cases of the lung carcinoma. Igaku no ayumi (Japanese edition) 1961;36:256-62.

6 Mooi WJ, Addis BJ. Carcinoma of the lung. In: Summers W StC, Corrin B, eds. Systemic pathology. 3rd edn. Vol 5. Th lung. Edinburgh: Churchill Livingstone, 1990:341-72.

7 Auerbach O, Garfinkel L, Parks VR. Histologic type of lung cancer in relation to smoking habits, year of diagnosis and site of metastasis. Chest 1975;67:382-7.

8 Carter D, Eggleston JC. Bronchogenic carcinoma, In Tumors of the lower respiratory tract. Atlas of Tumor Pathology Second series, fascicle 17. Washington, DC: Armed Forces Institute of Pathology, 1980:59-69.

9 Oono Y, Kubo N, Hayashi Y. In: Annual Report of Kitsuen Kagaku Fundation. Tokyo: Japan Tobacco Co., 1988:5-17.

10 Bejui-Thivolet F, Liagre N, Chignol MC, Chardonnet Y, Patricot LM. Detection of human papillomavirus DNA in squamous bronchial metaplasia and squamous cell carcinoma of the lung by in situ hybridization using biotinylated probes in paraffin-embedded specimens. Hum Pathol 1990; 21:111-16.

11 Yousen SA, Ohori NP, Sinmez-Alpan E. Occurrence of human papillomavirus DNA in primary lung neoplasms. human papillomavirus

12 Watts SL, Brewer EE, Fry TL. Human papillomavirus DNA types in squamous cell carcinomas of the head and neck. Oral Surg Oral Med Oral Pathol 1991;71:701-7.
13 Chang KW, Chang C-S, Lai K-S, Chou M-J, Choo K-B. High prevalence of human papillomavirus infection and possible association with Betel quid chewing and smoking in oral epidermoid carcinomas in Taiwan. 7 Med Virol 1989;28:57-61.

14 Warren S, Gates O. Multiple primary malignant tumors. A study of the literature and a statistical study. $A m \mathcal{F}$ Cancer 1932;16:1358-414.

15 Cooper K, Herrington CS, Stickland JE, Evans MF, McGree JO'D. Episomal and integrated human papillomavirus in cervical neoplasia shown by non-isotopic in situ hybridisation. $\mathcal{F}$ Clin Pathol 1991;44:990-6.

16 Impraim CC, Saiki RK, Erlich HA, Teplitz RL. Analysis of DNA extracted from formalin-fixed, paraffin-embedded tissues by enzymatic amplification and hybridization with sequence-specific oligonucleotides. Biochem Biophys Res Commum 1987;142:710-16.

17 Saiki RK, Scharf S, Faloona F, Mullis KB, Horn GT, Erlich $\mathrm{HA}$, et al. Enzymatic amplification of $\beta$-globin genomic sequences and restriction site analysis for diagnosis of sickle cell anemia. Science 1985;230:1350-4

$18 \mathrm{McNicol}$ P, Paraskevas M, Guijon F. Variability of polymerase chain reaction-based detection of human papillomavirus DNA is associated with the composition of vaginal microbial flora. 7 Med Virol 1994;43:194-200.

19 Engelke DR, Hoener PA, Collins FS. Direct sequencing of enzymatically amplified human genomic DNA. Proc Natl Acad Sci USA 1988;85:544-8.

20 Mierendorf $R$, Pfeffer D. Direct sequencing of denatured plasmid DNA. In: Berger SL, Kimmel AR, eds. Methods in enzymology. Guide to mlecular cloning technique. San Diego: Academic Press, 1987:556-62.

21 Cole ST, Danos O. Nucleotide sequence and comparative analysis of the human papillomavirus type 18 genome. $f$ Mol Biol 1987;293:599-608.

22 Shamanin V, Delius H, De Villiers E-M. Development of a broad spectrum PCR assay for papillomaviruses and its application in screening lung cancer biopsies. $\mathcal{F}$ Gen Virol 1994:1149-156.

23 Barnes W, Delgado G, Kurman RJ, Petrieli ES, Smith DM, Ahmed S, et al. Possible prognostic significance of human papillomavirus type in cervical cancer. Gynecol Oncol 1988; 29:267-73

24 Bergeron C, Barrasso R, Beaudenon S, Flamant P, Croissant O, Orth G. Intraepithelial neoplasia. Great diversity and distinct distribution in low-and high-grade lesions. Am 7 Surg Pathol 1992;16:641-9.

25 Mclachlin CM, Tate JH, Zirz JC, Sheets EE, Crum CP. Human papillomavirus type 18 and intraepithelial lesions of the cervix. Am $\Im$ Pathol 1994;144:141-7.

26 Wilczynski SP, Bergen S, Walker J, Liao Sy, Pearlman LF Human papillomaviruses and cervical cancer: analysis of histopathologic features associated with different viral types. Hum Pathol 1988;19:697-704

27 Willett GD, Kurman RH, Reid R, Greenberg M, Jenson AB, Lorincz AT. Correlation of the histologic appearance of intraepithelial neoplasia of the cervix with human papillomavirus types. Int 7 Gynecol Pathol 1989;8:18-25.

28 Zur Hausen H. Papillomaviruses as carcinomaviruses. In: Klein G, ed. Advences in viral oncology. New York: Raven Press, 1989:1-26.

29 Vousden $\mathrm{KH}$. Cell transformation by human papillomaviruses. In: Minson J, Neil J, McGrae M, eds. Viruses and cancer. Cambridge: Cambridge University Press, 1994:2746.

30 Schneider A. Natural history of genital papillomavirus infections. Intervirology 1994;37:201-14.

31 Uchima E, Kaiiwara M, Mukai T, Ohno Y, Nagamori $H$, Miyazaki T, et al. Distribution of $\mathrm{Gm}$ allotypes among the three populations of the Miyako islands in Okinawa. $f_{p n} \mathcal{f}$ Legal Med 1989;43:310-14.

32 Altmann A, Jochmus I, Rosl F. Intra-and extracellular control mechanisms of human papillomavirus infection. Intervirology 1994;37:180-8.

33 Glew SS, Stern PL, Davidson JA, Dyer PA. HLA antigens and cervical carcinoma. Nature 1992;356:22.

34 Helland A, Borresen AL, Kaern J, Ronningen KS, Thorsby E. HLA antigens and cervical carcinoma. Nature 1992;356: 23 .

35 Wank R, Thomssen C. High risk of squamous cell carcinoma of the cervix for women with HLA-DQW3. Nature 1991;352:723-5. 